\title{
The effect of haemonchosis and blood loss into the abomasum on digestion in sheep
}

\author{
BY J. B. ROWE ${ }^{1}$, J. V. NOLAN ${ }^{2}$, G. DE CHANEET ${ }^{1}$ AND E. TELEN I ${ }^{*}$ \\ ${ }^{1}$ Division of Animal Production, Department of Agriculture, Baron-Hay Court, \\ South Perth, Western Australia 6151, Australia \\ ${ }^{2}$ Department of Biochemistry, Microbiology and Nutrition, University of New England, \\ Armidale, NSW 2351, Australia \\ AND P. H. HOLMES \\ Department of Veterinary Physiology, University of Glasgow Veterinary School, \\ Bearsden Road, Glasgow
}

(Received 22 January 1987 - Accepted 4 September 1987)

1. An experiment was conducted to determine the effect of the abomasal parasite, Haemonchus contortus, on the pattern of digestion and nutrient utilization in Merino sheep. There were three groups of sheep: infected with $H$. contortus ( 300 larvae/ $\mathrm{kg}$ live weight) $(n)$ ), sham-infected by transferring blood from the jugular vein to the abomasum, and uninfected (control) sheep $(n 9)$ which were fed daily rations equal to amounts consumed by 'paired' animals in the two other treatment groups. A diet containing $(\mathrm{g} / \mathrm{kg}$ ): lucerne (Medicago sativa) chaff 490 , oat chaff 480 , ground limestone 10 , urea 10 , and sodium chloride 10 , was given in equal amounts at 3-h intervals.

2. Continuous intrarumen infusions ( $8 \mathrm{~d}$ ) of chromium and ytterbium were made in order to measure the flow of digesta through the rumen, duodenum and ileum with ${ }^{15} \mathrm{NH}_{4} \mathrm{Cl}$ included in the infusate for the final $3 \mathrm{~d}$. The loss of blood into the gastrointestinal tract was measured using ${ }^{51} \mathrm{Cr}$-labelled erythrocytes and the rate of irreversible loss of plasma urea was measured with reference to a single intravenous injection of $\left[{ }^{14} \mathrm{C}\right]$ urea. Samples of rumen fluid were taken for analysis of volatile fatty acid (VFA) concentrations.

3. The infected and sham-infected sheep developed severe anaemia during the period over which digestion and metabolism measurements were made (packed cell volume 0.118 (SE 0.0042) and 0.146 (SE 0.0073) respectively). The corresponding rates of blood loss into the gastrointestinal tracts were 253 (SE 23) and 145 (SE 17) $\mathrm{ml} / \mathrm{d}$.

4. The proportions of VFA in rumen fluid were altered $(P<0.05)$ in the infected group with a decrease in the ratio, acetate: propionate (control $3 \cdot 28$, infected $2 \cdot 58$, standard error of difference (SED) $0 \cdot 21$ ). There was also an increase in rumen fluid outflow rate $(P<0.01)$ from 4.05 litres/d in the control group to 5.53 litres/d in the infected group (SED 0.43). Water intake was higher $(P<0.05)$ in the infected than in the control animals $(2.25$ and 1.84 litres/d respectively; SED 0.14$)$.

5. There was a decrease $(P<0.05)$ in apparent digestion of organic matter in the forestomachs of infected sheep $(0.32$ compared with 0.39 in the control, SED 0.02). There was also a decrease $(P<0.05)$ in the apparent digestion of organic matter across the whole digestive tract $(0.65$ control, 0.61 infected, SED 0.013$)$,

6. There was a loss of 2.6 and $1.8 \mathrm{~g}$ blood nitrogen $/ \mathrm{d}$ into the gastrointestinal tract of the infected and shaminfected sheep respectively. In the infected sheep approximately $50 \%$ of this $\mathrm{N}$ was accounted for as additional ammonia leaving the abomasum compared with $20 \%$ in the sham-infected group. The additional nonammonia-N (NAN) entering the duodenum of parasitized or sham-infected animals was reabsorbed before the ileum. There was no effect of infection or sham-infection on the synthesis or digestion of microbial NAN.

7. There was a higher $(P<0.001)$ rate of plasma urea irreversible loss in the infected sheep $(8.9$ control, 12.2 infected, 10.9 sham-infected, SED (control $v$. treated) $0.87 \mathrm{~g} \mathrm{~N} / \mathrm{d}$ ). This was apparently due to increased absorption of ammonia and increased urea excretion and transfer to the gut.

8. The results show that in sheep infected with $H$. contortus there was a considerable increase in the amount of additional endogenous $\mathrm{N}$ entering the duodenum. Although the extra $\mathrm{N}$ lost into the gastrointestinal tract was reabsorbed before the digesta reached the ileum the animals suffered a net loss of amino acids since part of the reabsorbed $\mathrm{N}$ was in the form of ammonia and reabsorbed NAN was apparently ineffectively utilized.

* Present address: Graduate School of Tropical Veterinary Science, James Cook University, Queensland 4811, Australia. 
Haemonchus contortus is a parasite of major economic importance in most sheep-rearing areas of the world. The larval and adult stages of $H$. contortus suck blood from the abomasal mucosa and severe anaemia can develop. Infected animals show poor growth rates (Allonby \& Dargie, 1973), reduced wool (Albers et al. 1984) and milk (Thomas \& Ali, 1983) production, and death can result from heavy infections.

Radio-tracer studies using ${ }^{51} \mathrm{Cr}$-labelled erythrocytes indicate that a daily blood loss of approximately $150-200 \mathrm{ml} / \mathrm{d}$ commonly occurs in sheep carrying burdens of $3000-4000$ worms (Dargie, 1975; Altaif \& Dargie, 1978; Abbott et al. 1986), but the extent to which the blood protein and amino acids lost into the gastrointestinal tract can be re-utilized is unclear. This and other effects which the parasitism has on digestive and metabolic processes have not yet been measured directly. Reduced nitrogen retention is a characteristic feature of nematode infections. In the majority of experiments this has been associated with increased urinary $\mathrm{N}$ loss (for review, see Holmes, 1985). However, $\mathrm{N}$ balance studies do not permit direct assessment of the levels of endogenous protein loss nor the fate of the proteins within the tract. Such information can only be obtained from studies with animals with gastrointestinal cannulas. Such studies have so far been limited to sheep infected with Ostertagia circumcincta (Steel, 1974, 1978) or Trichostrongylus colubriformis (Poppi et al. 1986 ) in which, in contrast to $H$. contortus infections, blood loss into the gastrointestinal tract does not occur. An exception was a preliminary study by Rowe et al. (1982) in cannulated sheep infected with $H$. contortus which showed that the blood $\mathrm{N}$ lost into the abomasum was reabsorbed before reaching the terminal ileum.

The experiment described here was designed to investigate the effect of $H$. contortus infection on flow and apparent digestion of $\mathrm{N}$, organic matter and energy in different parts of the gastrointestinal tract of sheep. In addition the effect of blood loss into the abomasum without the associated trauma of parasitic infection of the abomasal mucosa was examined in uninfected sheep by removing blood from a jugular vein and infusing it into the abomasum of the same animal through an indwelling abomasal cannula.

\section{EXPERIMENTAL}

Animals and diets

Twenty-four Merino wethers ( 9 months of age) were selected for similar live weight $(24.7$ $(\mathrm{sE} 0.7) \mathrm{kg}$ ) from a flock of 200 in an arid area of Western Australia where haemonchosis is rarely found in sheep. Indwelling silicone (Dow Corning, Australia) cannulas (10 mm internal diameter (i.d.)) were placed in the rumen, proximal duodenum and terminal ileum of all sheep. A further silicone cannula $(1.5 \mathrm{~mm}$ i.d.) was placed in the abomasum of ten sheep, selected at random. All surgery was carried out with sheep under general anaesthesia (Nembutal ${ }^{\circledR}, 60 \mathrm{mg}$ sodium pentobarbitone/ml; CEVA Chemicals, Australia). There was a period of approximately 6 weeks following surgery before the experimental programme started. At 2 weeks after surgery all sheep were given two doses of oxfendazole $(10 \mathrm{mg} / \mathrm{kg}$ live weight) (Systamex ${ }^{\circledR}$; Coopers Animal Health, Australia) with an interval of $4 \mathrm{~d}$ between the first and second dose, to ensure the absence of all intestinal nematodes. Faecal egg counts were measured twice weekly from this time until the start of the experiment. Animals were housed individually from after surgery until the end of the experimental period. The diet to be used during the experiment $(\mathrm{g} / \mathrm{kg}$ : lucerne (Medicago sativa) chaff 490 , oat chaff 480 , ground limestone 10 , urea 10 , sodium chloride 10 ) was fer ad lib. and daily feed intakes were recorded during the post-operative period. A maxim $\mathrm{m}$ ration of $650 \mathrm{~g} / \mathrm{d}$ (approximately $90 \%$ of ad lib.) was offered during the experimental period. When in metabolism cages, animals were given the daily ration in eight equal amounts at intervals of $3 \mathrm{~h}$. 
Daily measurements were made of feed and water intakes and of faeces and urine voided over a $10 \mathrm{~d}$ period during the experiments. Urine was collected into a reservoir containing $20 \mathrm{ml}$ concentrated sulphuric acid.

\section{Experimental protocol}

The experiment was carried out over a $52 \mathrm{~d}$ period. On day 1 seven sheep were infected via the rumen cannula with $H$. contortus ( 300 larvae $/ \mathrm{kg}$ live weight) from a strain recently isolated from the field. Larvae were initially cultured from the faeces of twelve grazing Merino wethers and passed through three pen-fed Merino wethers before infection of the experimental sheep. $15 \mathrm{~d}$ later, five of these animals and five uninfected animals with abomasal cannulas were placed in metabolism cages. On day 22 , the latter group (the shaminfected group) was prepared with indwelling jugular catheters and on day $23,50 \mathrm{ml}$ blood were removed into heparinized syringes. This blood was then infused into the abomasum of the animal from which it had been taken, over the following $24 \mathrm{~h}$ using a variable-speed peristaltic pump. The volume of blood removed and re-infused in this way was increased daily in $25-\mathrm{ml}$ increments to $150 \mathrm{ml} / \mathrm{d}$ by day 27 , and maintained at this level until day 40 . Blood packed cell volume and live-weight changes were measured regularly throughout the experiment. Faecal egg counts were made from the parasitized animals on days 13-15, 18-21 and then daily from day 24 to day 42 of the infection. From day 29 to day 40 a series of tracer injections and infusions was conducted in addition to a complete balance study in which feed and water intake and output of faeces and urine were measured. On day 29 autologous ${ }^{51} \mathrm{Cr}$-labelled erythrocytes $(10 \mathrm{MBq} /$ animal) were injected to measure the rate of blood loss into the gastrointestinal tract. From day 32 to day 39, ytterbium acetate $(0.15 \mathrm{~g} / 1)$ and CrEDTA (Binnerts et al. 1968) (approximately $0.3 \mathrm{~g} \mathrm{Cr} / 1$ ) were infused via separate infusion lines into the rumen, each at approximately $0.3 \mathrm{ml} / \mathrm{min}$. During the final $3 \mathrm{~d}$ of these infusions ${ }^{15} \mathrm{NH}_{4} \mathrm{Cl}\left(96\right.$ atoms ${ }^{15} \mathrm{~N} / 100$ atoms $\left.\mathrm{N}\right)$ was included in the CrEDTA solution $\left(0.17 \mathrm{~g}^{15} \mathrm{NH}_{4} \mathrm{Cl} / 1\right)$. Over the last $36 \mathrm{~h}$ of infusion, seven samples of rumen fluid, four of rumen microbes, six of duodenal digesta and four of ileal digesta were taken. On day 36 each sheep was given an intravenous injection of $\left[{ }^{14} \mathrm{C}\right]$ urea $(2.59 \mathrm{MBq}, 50 \mathrm{mg})$ in $10 \mathrm{ml}$ isotonic saline $(0.9 \mathrm{~g} \mathrm{NaCl} / 1)$ and blood samples taken at intervals of $0,15,30,60,120,240$, $360,540,720,1320$ and $1440 \mathrm{~min}$ afterwards for measurement of specific radioactivity. On day 42 the parasitized animals were anaesthetized and then slaughtered, and a total count of $H$. contortus present in the abomasum was made. The $\mathrm{pH}$ of the abomasal digesta was also measured.

Ten of the remaining uninfected sheep were used as pair-fed controls. During days 40-50, five were individually pair-fed with the parasitized animals and five (with abomasal cannulas) with the sham-infected animals so that the amount of feed offered corresponded with the intakes of the parasitized and sham-parasitized animals on days 30-40. A similar series of infusions and measurements was made on the control animals from days 41 to 50 as had previously been conducted on the parasitized and sham-parasitized animals from days 31 to 40 . All sheep were weighed $4 \mathrm{~d}$ before the infection of the parasitized group, on day 15 after infection, and at the time that they were taken out of the metabolism cages.

\section{Sample collection and preparation}

Duodenal and ileal samples were stored at $-20^{\circ}$ before being bulked within sheep by combining approximately $20 \%$ of each similar sample. Subsamples were removed from the well-mixed, bulked sample for analysis of $\mathrm{N}$ and ${ }^{15} \mathrm{~N}$ (both ammonia and non-ammonia$\mathrm{N}$ (NAN)), dry matter, ash, $\mathrm{Yb}$ and $\mathrm{Cr}$, and for preparation of a supernatant fraction by centrifugation $(25000 \mathrm{~g}$ for $20 \mathrm{~min}$ ) of whole digesta. The supernatant fluid was analysed 
for ammonia, NAN, dry matter, organic matter, $\mathrm{Cr}$ and $\mathrm{Yb}$. Rumen bacterial fractions for ${ }^{15} \mathrm{~N}$ analysis were prepared by differential centrifugation of rumen fluid (Leng et al. 1981) and stored at $-20^{\circ}$. Subsamples of rumen fluid were acidified $(\mathrm{pH}<2)$ with $10 \mathrm{M}-\mathrm{H}_{2} \mathrm{SO}_{4}$ and stored $\left(-20^{\circ}\right)$ for analysis of ${ }^{15} \mathrm{NH}_{3}$ and $\mathrm{Cr}$ (analysed on individual samples) and a bulked sample $\left(10 \%\right.$ of each individual sample) stored $\left(-20^{\circ}\right)$ for analysis of volatile fatty acids (VFA). Feed and faeces were dried at $80^{\circ}$ for $24 \mathrm{~h}$, and acidified urine was stored at $-20^{\circ}$ for analysis of total $\mathrm{N}$ and urea concentrations. Blood samples were taken into heparinized containers, centrifuged at $3000 \mathrm{~g}$ for $10 \mathrm{~min}$ and the plasma stored at $-20^{\circ}$.

Blood samples for ${ }^{51} \mathrm{Cr}$ labelled erythrocyte measurements were collected each day in heparinized containers and $1 \mathrm{ml}$ portions prepared for radioactivity determination by dilution with $9 \mathrm{ml} 0.002 \mathrm{M}$-sodium hydroxide. The radioactivity in weighed subsamples of faeces was also determined each day.

\section{Analytical methods}

Organic matter was determined by ashing at $550^{\circ}$ for $16 \mathrm{~h}$. Ammonia and NAN in digesta fractions were collected and measured by distillation and Kjeldahl digestion, and their enrichment with ${ }^{15} \mathrm{~N}$ determined by mass spectrometry (Nolan \& Leng, 1972). Gross energy measurements were made using a ballistic bomb calorimeter (Gallenkamp, England). VFA were measured using gas-liquid chromatography (PYE series 104) with phosphoric acid on 100/120 Chromasorb W Aw (Supelco 1-2144) as the stationary phase. The Cr content of rumen fluid and the $\mathrm{Yb}$ and $\mathrm{Cr}$ contents of the fluid-phase of duodenal and ileal digesta were measured by atomic absorption using direct aspiration of sample fluid $(1 \mathrm{ml})$ diluted with $3 \mathrm{ml}$ acid solution (2.25 M-hydrochloric acid, $2.25 \mathrm{M}$-nitric acid and $2 \mathrm{mg}$ potassium chloride $/ \mathrm{ml}$ ) as described by Siddons et al. (1985). $\mathrm{Cr}$ was measured using an acetylene--oxygen flame and $\mathrm{Yb}$ using an acetylene-nitrous oxide flame. $\mathrm{Cr}$ and $\mathrm{Yb}$ in dried digesta samples were measured as described previously but samples were first ashed and extracted in acid solution as described by Siddons et al. (1985) for $\mathrm{Yb}$. To overcome problems associated with matrix interferences (Siddons et al. 1985), standards were prepared by adding known amounts of $\mathrm{Cr}$ and $\mathrm{Yb}$ to blank rumen fluid, fresh digesta and faeces which were then prepared in the same way as corresponding samples. The concentration of urea in plasma and in urine was measured as described by Marsh et al. (1957). Plasma samples containing $\left[{ }^{14} \mathrm{C}\right]$ urea were assayed for radioactivity, following deproteinization, in a liquid-scintillation counter (Packard Instrument Co, USA) using toluene-Triton-X $(9: 4, \mathrm{v} / \mathrm{v})$ as scintillant (see Nolan \& Leng, 1972).

The ${ }^{51} \mathrm{Cr}$ activity of blood and faecal samples was determined in an Automatic Gamma Scintillation Counter (Packard Instrument Co, USA).

Worm eggs in faeces were counted using a modified McMaster technique (Gordon \& Whitlock, 1939).

\section{Calculations}

The flows of digesta constituents through the duodenum and ileum were calculated by reference to $\mathrm{Yb}$ and $\mathrm{Cr}$ as dual-phase markers by methods similar to those described by Faichney (1975). The enrichment ratio $\left({ }^{15} \mathrm{~N}\right.$ in digesta NAN : ${ }^{15} \mathrm{~N}$ in microbial $\left.\mathrm{N}\right)$ was used to calculate rumen microbial flow at the duodenum and ileum assuming that all ${ }^{15} \mathrm{~N}-\mathrm{NAN}$ in duodenal and ileal digesta was in rumen microbial material. The utilization of ammonia in, and absorption from the forestomachs was calculated as described by Siddons et al. (1985). The rate of irreversible loss of urea from plasma (urea production rate in the body) was estimated from the specific radioactivity of urea-C in plasma after intravenous injection of $\left[{ }^{14} \mathrm{C}\right]$ urea, assuming the values were well fitted by a single exponential function (see Cocimano \& Leng, 1967). 
The loss of blood into the gastrointestinal tract $(\mathrm{ml} / \mathrm{d})$ was determined from the daily total ${ }^{51} \mathrm{Cr}$ excreted in the faeces divided by the ${ }^{51} \mathrm{Cr}$ activity $/ \mathrm{ml}$ blood at the beginning of each 24 h collection period. Blood $\mathrm{N}$ entering the abomasum was calculated from the blood loss and the $\mathrm{N}$ content of blood as affected by packed cell volume.

The live-weight changes given in Table 2 (p. 132) are for the periods: days 15-39 (parasitized and sham-infected groups); and days 15-50 (control group).

\section{Statistical analysis}

Treatment effects on indices of rumen function, digesta and metabolite flows were expected to be influenced by level of feed intake. Before analysis of variance, each variate was checked for a linear relation with feed intake (dry matter, organic matter or total $\mathrm{N}$ ) and, where this was significant, feed intake was included in the analysis as a covariate.

The covariate analysis has the effect of adjusting all data to a common level of feed intake. The covariate coefficient is the estimate of the slope between feed intake and the data variable. The covariate analyses were adopted after checking that the data did not violate the assumptions of the analysis. That is, there was no significant effect of treatments on the covariate (the design ensured considerable overlap in intake levels between all treatment groups). Where the covariate was significant a separate analysis of the data was applied to test for treatment effects on the linear relation. These effects were not significant for any of the variables.

In Tables 1-6 the significance of the $F$ ratio is given for each variable together with two standard errors of difference (SED) to allow comparison between means of unequal groups. Where the covariate was significant $(P<0.05)$, the results of adjusted analysis and the coefficients are given. Where the covariate was non-significant, results are from the unadjusted analysis.

\section{RESULTS}

The absence of helminth infection at the start of the experiment was confirmed by the absence of worm eggs in faeces. The parasitological and haematological findings are presented in Fig. 1. The sheep inoculated with $H$. contortus developed positive faecal egg counts by day 18 and maintained high faecal egg counts until day 40 . At slaughter the infected group of sheep had a mean worm burden of 5008 (SE 278), representing a mean establishment of $67 \%$. Establishment of the parasites in the abomasum was associated with the development of a severe anaemia (Fig. 1) and the infected sheep had a mean packed cell volume of 0.118 (SE 0.0042 ) by day 40 . Mean blood loss into the gastrointestinal tract estimated using ${ }^{51} \mathrm{Cr}$-labelled erythrocytes was 253 (SE 23) $\mathrm{ml} / \mathrm{d}$ in the infected sheep (Fig. 1). The sham-parasitized sheep also developed a severe anaemia, while in the control sheep there was only a small fall in packed cell volume (Fig. 1). Faecal measurements of ${ }^{51} \mathrm{Cr}$-labelled erythrocyte losses into the gastrointestinal tract of sham-parasitized sheep confirmed a mean daily loss of 145 (SE 17) $\mathrm{ml} / \mathrm{d}$ while there were very low blood losses in the control group (mean $3.6(\mathrm{SE} 1.2) \mathrm{ml} / \mathrm{d}$ ).

The diet contained ( $/ \mathrm{kg}$ dry matter): $915 \mathrm{~g}$ organic matter, $14.4 \mathrm{~g}$ crude protein $(\mathrm{N} \times 6.25$; $22 \%$ of this as urea) and $15.3 \mathrm{MJ}$ gross energy. The digestible energy content of the diet measured in the control group was $9.55 \mathrm{MJ} / \mathrm{kg} \mathrm{DM}$. Although pair-fed there were some feed refusals in the control sheep and actual feed intakes were slightly different between groups. Feed intake by one sheep in the control group was variable and values from this animal were not analysed.

Rumen measurements are given in Table 1. Rumen fluid $\mathrm{pH}$ and total VFA concentrations did not differ $(P>0.05)$ between the treatments. However, there were significant differences between the molar percentages of acetate and propionate in rumen 

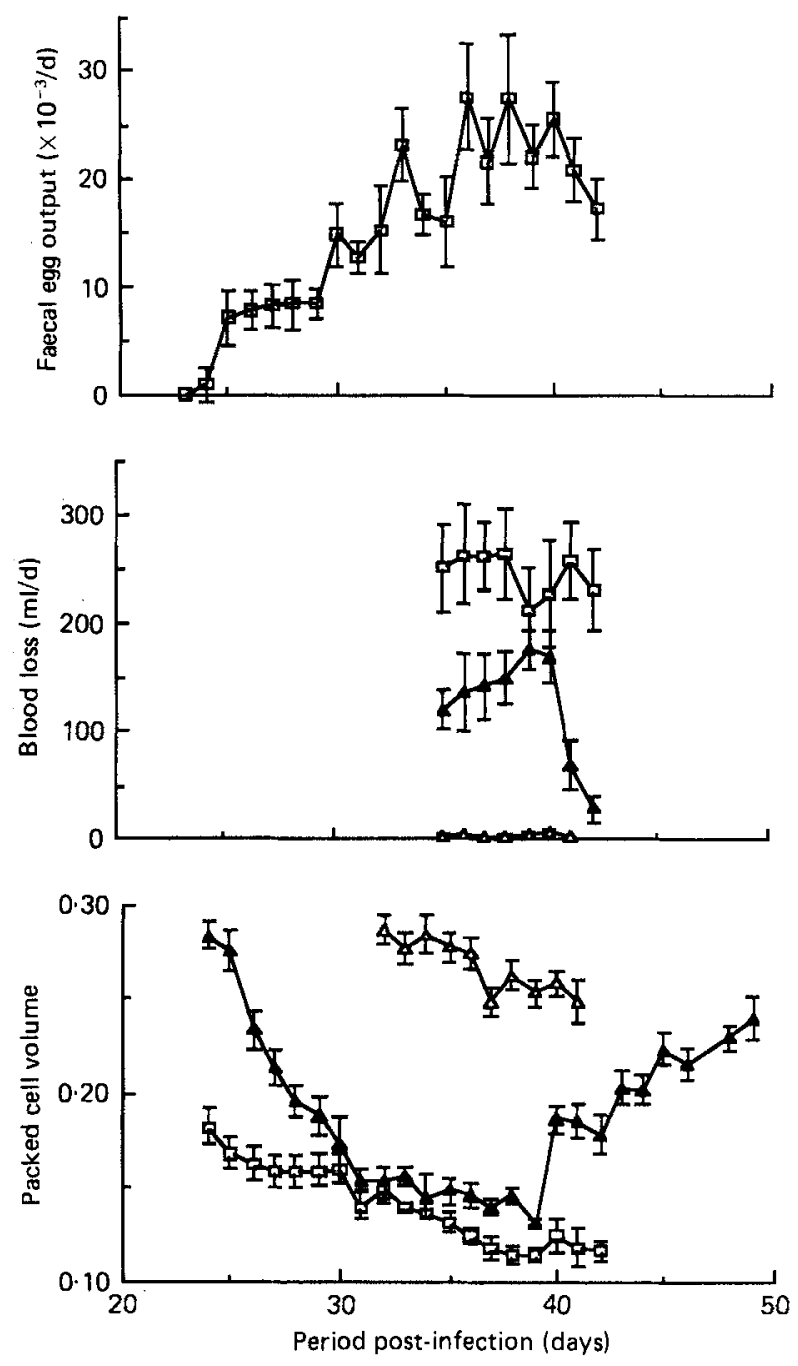

Fig. 1. Parasitological and haematological changes with time in uninfected sheep (control) $(n 9 ; \Delta)$, following infection with Haemonchus contortus $(n 5 ; \square)$ or sham-infection through jugular-abomasal blood transfer $(n 5 ; \boldsymbol{\Delta})$. The uninfected sheep were pair-fed with the parasitized and sham-infected animals. Values are means, with their standard errors represented by vertical bars.

fluid resulting in a decrease in the ratio, acetate:propionate between the control and infected animals. The $\mathrm{pH}$ of abomasal contents of the parasitized sheep, measured at the completion of the experiment, was 3.0 (SE 0.2 ).

There were no significant differences in organic matter intake between parasitized, shaminfected animals and the control group. The organic matter flows at the duodenum and in faeces were significantly $(P<0.05)$ higher in the infected animals than in the pair-fed controls and this difference in organic matter flows was reflected by significant differences in the flows of energy (see Table 2). There was on average a smaller loss of live weight $(-11 \mathrm{~g} / \mathrm{d})$ in the parasitized group than in the control group $(-66 \mathrm{~g} / \mathrm{d})(P<0.01)$.

The input of blood $\mathrm{N}$ into the abomasum of sham-infected animals was calculated from 
Table 1. Rumen $\mathrm{pH}$ and volatile fatty acids (VFA) measured in sheep: uninfected (control), infected with Haemonchus contortus or sham-infected by jugular-abomasal blood transfer

\begin{tabular}{|c|c|c|c|c|c|c|}
\hline$n \quad \ldots$ & $\begin{array}{c}\text { Control } \\
\text { (C) } \\
9\end{array}$ & $\begin{array}{l}\text { Parasitized } \\
\text { (P) } \\
5\end{array}$ & $\begin{array}{l}\text { Sham } \\
\text { (S) } \\
5\end{array}$ & $\begin{array}{l}\text { SED } \\
C v . P \\
C v . S\end{array}$ & $\begin{array}{c}\text { SED } \\
\mathrm{P} v . \mathrm{S}\end{array}$ & $\begin{array}{c}\text { Statistical } \\
\text { significance } \\
\quad(F \text { test })\end{array}$ \\
\hline $\mathrm{pH}$ & $6 \cdot 75$ & $6 \cdot 77$ & $6 \cdot 84$ & $0 \cdot 12$ & $0 \cdot 13$ & NS \\
\hline Total VFA (mmol/1) & $42 \cdot 8$ & $47 \cdot 0$ & $43 \cdot 4$ & $4 \cdot 6$ & $5 \cdot 3$ & NS \\
\hline $\begin{array}{l}\text { VFA (mmol/mol): } \\
\text { Acetate } \\
\text { Propionate } \\
\text { Butyrate }\end{array}$ & $\begin{array}{c}668 \\
207 \\
95\end{array}$ & $\begin{array}{l}628 \\
244 \\
102\end{array}$ & $\begin{array}{l}636 \\
231 \\
107\end{array}$ & $\begin{array}{c}10 \\
11 \\
7\end{array}$ & $\begin{array}{c}12 \\
13 \\
8\end{array}$ & $\stackrel{* *}{*}$ \\
\hline Acetate:propionate & $3 \cdot 28$ & $2 \cdot 58$ & $2 \cdot 77$ & 0.21 & 0.24 & $*$ \\
\hline
\end{tabular}

$n$, number of sheep per treatment; SED, standard error of difference; NS, not significant.

* $P<0.05, * * P<0.01$.

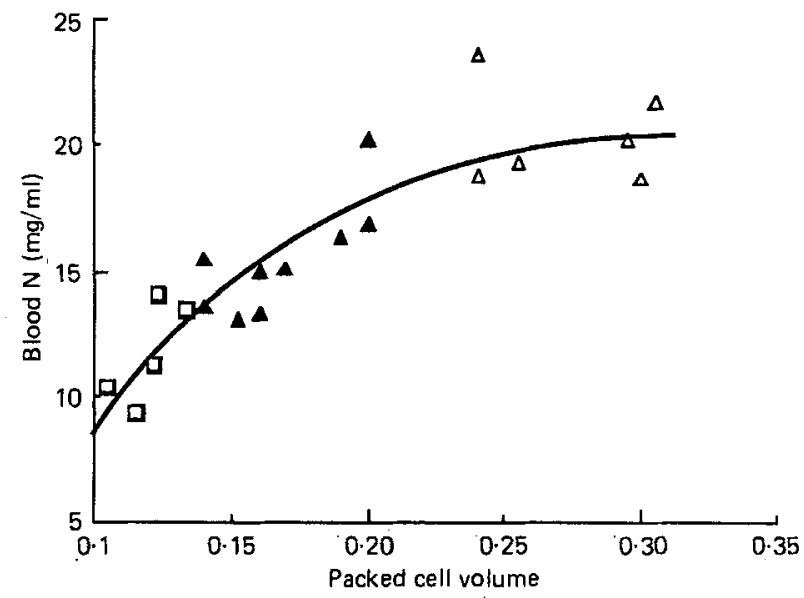

Fig. 2. The relation between packed cell volume and blood nitrogen concentration in sheep: uninfected (control) $(\triangle)$, infected with Haemonchus contortus $(\square)$, or sham-infected through jugular-abomasal blood transfer $(\mathbf{A})$.

$$
y=-6.37+186 x-321 x^{2} \quad(R 0.92)
$$

the $\mathrm{N}$ content of the blood (see Fig. 2) and the loss of blood into the abomasum either measured directly (sham-infection) or using ${ }^{51} \mathrm{Cr}$-labelled erythrocytes. In the parasitized animals $2.6 \mathrm{~g} \mathrm{~N} / \mathrm{d}$ entered the abomasum in this way and in the sham-infected group $1.8 \mathrm{~g} \mathrm{~N} / \mathrm{d}$.

Principally as a result of more $\mathrm{N}$ being excreted in the urine, less $\mathrm{N}$ was retained in the body of infected animals than in their controls (see Table 3). The apparent absorption coefficients for organic matter, gross energy and $\mathrm{N}$ in different parts of the digestive tract are given in Table 4. Differences in the apparent absorption coefficients for organic matter and gross energy in the whole digestive tract between infected animals and their controls appear to result from differences in the extent of fermentation in the forestomachs (see Table 4). There were no significant differences in the digestibility of organic matter in 
Table 2. Intake and flow of organic matter $(g / d)$ and energy $(M J / d)$ through the digestive tract of and live-weight change $(\mathrm{g} / \mathrm{d})$ in sheep: uninfected (control), infected with Haemonchus contortus or sham-infected by jugular-abomasal blood transfer

(Covariate:organic matter intake (g/d); grand mean $394 \mathrm{~g} / \mathrm{d}$ )

\begin{tabular}{|c|c|c|c|c|c|c|c|}
\hline$n \quad \ldots$ & $\begin{array}{c}\text { Control } \\
\text { (C) } \\
9\end{array}$ & $\begin{array}{c}\text { Parasitized } \\
\text { (P) } \\
5\end{array}$ & $\begin{array}{l}\text { Sham } \\
(\mathrm{S}) \\
5\end{array}$ & $\begin{array}{l}\text { SED } \\
\mathrm{C} v \cdot \mathrm{P} \\
\mathrm{C} v \cdot \mathrm{S}\end{array}$ & $\begin{array}{c}\text { SED } \\
\text { P v. S }\end{array}$ & $\begin{array}{c}\text { Statistical } \\
\text { significance } \\
(F \text { test })\end{array}$ & $\begin{array}{l}\text { Covariate } \\
\text { coefficient }\end{array}$ \\
\hline \multicolumn{8}{|c|}{ Organic matter $(\mathrm{g} / \mathrm{d})$ : } \\
\hline Intake & 382 & 447 & 362 & $68 \cdot 5$ & $77 \cdot 7$ & NS & - \\
\hline At duodenum & 243 & 272 & 251 & $10 \cdot 1$ & $11 \cdot 4$ & $*$ & 0.63 \\
\hline At ileum & 158 & 172 & 165 & 64 & $7 \cdot 2$ & NS & $0 \cdot 35$ \\
\hline In faeces & 139 & 153 & 148 & $6 \cdot 1$ & $7 \cdot 0$ & $*$ & $0 \cdot 37$ \\
\hline \multicolumn{8}{|l|}{ Energy $(\mathrm{MJ} / \mathrm{d})$ : } \\
\hline Intake & $6 \cdot 40$ & 7.49 & 6.05 & $1 \cdot 12$ & $1 \cdot 34$ & NS & - \\
\hline At duodenum & $4 \cdot 52$ & $5 \cdot 32$ & 5.01 & $0 \cdot 17$ & $0 \cdot 19$ & $* * *$ & $0 \cdot 011$ \\
\hline At ileum & $2 \cdot 90$ & $3 \cdot 25$ & 2.99 & $0 \cdot 18$ & $0 \cdot 21$ & NS & 0.0058 \\
\hline In faeces & $2 \cdot 49$ & $2 \cdot 80$ & $2 \cdot 66$ & $0 \cdot 11$ & 0.13 & $*$ & 0.0059 \\
\hline $\begin{array}{l}\text { Live-weight } \\
\text { change }(\mathrm{g} / \mathrm{d})\end{array}$ & -66 & -11 & -74 & $16 \cdot 9$ & $19 \cdot 2$ & $* *$ & 0.277 \\
\hline
\end{tabular}

$n$, number of sheep per treatment; SED, standard error of difference; NS, not significant.

* $P<0.05,{ }^{* *} P<0.01,{ }^{* * *} P<0.001$

the postrumen part of the digestive tract. Total $\mathrm{N}$ intakes were not significantly different between infected animals and their pair-fed controls. The flow of total $\mathrm{N}$ at the duodenum was significantly $(P<0.01)$ higher in the parasitized animals owing to a greater flow of non-microbial NAN (Table 3) and of ammonia (Table 5). There was a higher apparent absorption of both NAN and ammonia from the small intestine in the parasitized and sham-infected animals and only the flow of ammonia was higher in the ileal digesta of the infected sheep (Table 5). There were no significant differences in the flow of rumen microbial-NAN either at the duodenum or ileum as a result of any treatment, with the absorption in the small intestine being 0.73 (SE 0.019). Although higher in the parasitized sheep the net microbial yield was not significantly different between treatments (Table 3 ) and for individual values was not significantly correlated with rumen fluid outflow.

The higher flows of ammonia at the duodenum in the infected animals were also reflected in higher flows of ammonia at the ileum even though plasma urea concentrations were not different between treatments (Table 5). The estimates of urea kinetics (Table 5) indicate that the urea pool size in the body and the rate of urea production were both significantly greater in the infected animals. Further, the rates of urinary excretion and transfer of this urea into the gut were greater $(p<0.05)$ in infected animals.

Water intake was significantly higher in the parasitized animals than in control animals but no significant difference occurred between the sham-infected and control animals (see Table 6). The higher water intake in the parasitized animals was associated with a higher rate of outflow from the rumen and a higher flow of water through the duodenum. The apparent flow of water into the forestomachs (negative apparent absorption coefficient) was higher $(P<0.05)$ in the sham-infected sheep than in either the control or parasitized animals. There was also a lower water content and a lower excretion of water in faeces of 
Table 3. Intake and flow of nitrogen through the digestive tract, urinary $N$ excretion, $N$ retention and microbial $N$ yield in sheep: uninfected (control), infected with Haemonchus contortus or sham infected by jugular-abomasal blood transfer

(Covariate: total $\mathrm{N}$ intake (g/d); grand mean $9.90 \mathrm{~g} / \mathrm{d}$ )

\begin{tabular}{|c|c|c|c|c|c|c|c|}
\hline$n \quad \ldots$ & $\begin{array}{c}\text { Control } \\
\text { (C) } \\
9\end{array}$ & $\begin{array}{l}\text { Parasitized } \\
\text { (P) } \\
5\end{array}$ & $\begin{array}{l}\text { Sham } \\
\text { (S) } \\
5\end{array}$ & $\begin{array}{l}\text { SED } \\
\mathrm{C} v \cdot \mathrm{P} \\
\mathrm{C} v \cdot \mathrm{S}\end{array}$ & $\begin{array}{l}\text { SED } \\
\mathrm{P} \text { v. S }\end{array}$ & $\begin{array}{c}\text { Statistical } \\
\text { significance } \\
(F \text { test })\end{array}$ & $\begin{array}{l}\text { Covariate } \\
\text { coefficient }\end{array}$ \\
\hline \multicolumn{8}{|l|}{ Total $N(g / d)$ : } \\
\hline Intake & $9 \cdot 61$ & $11 \cdot 23$ & 9.09 & $1 \cdot 72$ & 1.95 & NS & - \\
\hline At duodenum & $8 \cdot 16$ & $11 \cdot 30$ & 9.63 & 0.71 & 0.80 & $* *$ & 0.66 \\
\hline At ileum & $2 \cdot 82$ & $2 \cdot 90$ & 2.99 & $0 \cdot 15$ & $0 \cdot 17$ & NS & 0.20 \\
\hline In faeces & $2 \cdot 35$ & $2 \cdot 66$ & 2.52 & $0 \cdot 14$ & $0 \cdot 16$ & NS & 0.19 \\
\hline In urine & $6 \cdot 47$ & $8 \cdot 67$ & $8 \cdot 00$ & 0.51 & 0.58 & $* *$ & 0.47 \\
\hline Retention in body & 0.96 & $-1 \cdot 55$ & -0.73 & 0.45 & 0.52 & $* * *$ & $0 \cdot 34$ \\
\hline \multicolumn{8}{|l|}{ Total NAN $(\mathrm{g} / \mathrm{d})$ : } \\
\hline Intake & $7 \cdot 53$ & $8 \cdot 81$ & $7 \cdot 13$ & $1 \cdot 3$ & 1.5 & NS & - \\
\hline At duodenum & $7 \cdot 44$ & $9 \cdot 29$ & 8.57 & $0 \cdot 59$ & 0.68 & $*$ & 0.61 \\
\hline At ileum & $2 \cdot 56$ & $2 \cdot 55$ & $2 \cdot 49$ & $0 \cdot 17$ & 0.19 & NS & 0.19 \\
\hline \multicolumn{8}{|l|}{$\begin{array}{l}\text { Rumen microbial } \\
\text { NAN }(g / d) \text { : }\end{array}$} \\
\hline At duodenum & $4 \cdot 38$ & $4 \cdot 15$ & $4 \cdot 20$ & $0 \cdot 70$ & 0.80 & NS & 0.40 \\
\hline At ileum & $1 \cdot 21$ & 0.91 & $1 \cdot 12$ & $0 \cdot 18$ & 0.21 & NS & 0.089 \\
\hline \multicolumn{8}{|l|}{$\begin{array}{l}\text { Non-microbial NAN } \\
(\mathrm{g} / \mathrm{d}) \text { : }\end{array}$} \\
\hline At duodenum & 3.07 & $5 \cdot 13$ & $4 \cdot 37$ & 0.52 & 0.59 & $* *$ & 0.21 \\
\hline At ileum & $1 \cdot 34$ & $1 \cdot 64$ & $1 \cdot 38$ & $0 \cdot 19$ & $0 \cdot 22$ & NS & $0 \cdot 094$ \\
\hline Microbial yield $\dagger$ & $29 \cdot 4$ & $33 \cdot 2$ & $28 \cdot 3$ & 4.84 & $5 \cdot 49$ & NS & NS \\
\hline
\end{tabular}

$n$, number of sheep per treatment; SED, standard error of difference; NS, not significant; NAN, nonammonia- $\mathrm{N}$.

* $P<0.05,{ }^{* *} P<0.01, * * * P<0.001$

$\dagger, \mathrm{g}$ microbial $\mathrm{N}$ passing to duodenum $/ \mathrm{kg}$ organic matter apparently fermented in forestomachs.

the infected animals despite the fact that the inflow of water into the large intestine via the ileum was not different between treatments. There was a trend $(P=0.063)$ for the apparent water retention in the parasitized animals $(0.87$ litres/d) to be higher than in the pair-fed controls $(0.52$ litres/d).

\section{DISCUSSION}

The results of the present experiment confirm and extend the findings of a preliminary study (Rowe et al. 1982). They show that in sheep infected with the abomasal nematode, $H$. contortus, there was a considerable amount of additional endogenous $\mathrm{N}$ leaving the abomasum. An important difference between the parasitized and sham-infected sheep in our study was that in the former group much of the additional $\mathrm{N}$ leaving the abomasum was as ammonia and in this group there was also a higher level of urea synthesis. In effect the presence of $H$. contortus increased the non-recoverable loss of amino acids into the gut and increased the protein requirements of parasitized animals. The results thereby confirm the view that a major effect of parasitic infections, apart from causing inappetence, is brought about by an increase in the minimum amino acid requirement.

While the results of the present study and the following discussion relate to $H$. contortus 
Table 4. Apparent absorption coefficients for organic matter, gross energy and nitrogen in different parts of the digestive tract of sheep: uninfected (control), infected with Haemonchus contortus, or sham-infected by jugular-abomasal blood transfer

\begin{tabular}{|c|c|c|c|c|c|c|}
\hline$n \quad \ldots$ & $\begin{array}{c}\text { Control } \\
\text { (C) } \\
9\end{array}$ & $\begin{array}{l}\text { Parasitized } \\
\text { (P) } \\
5\end{array}$ & $\begin{array}{l}\text { Sham } \\
\text { (S) } \\
5\end{array}$ & $\begin{array}{c}\text { SED } \\
\text { C v. P } \\
\text { C v. S }\end{array}$ & $\begin{array}{c}\mathrm{SED} \\
\mathrm{P} v . \mathrm{S}\end{array}$ & $\begin{array}{c}\text { Statistical } \\
\text { significance } \\
\quad(F \text { test })\end{array}$ \\
\hline \multicolumn{7}{|l|}{ Whole digestive tract: } \\
\hline Organic matter & 0.65 & 0.61 & 0.62 & $0 \cdot 013$ & $0-015$ & $*$ \\
\hline Gross energy & 0.62 & 0.58 & 0.59 & 0.014 & $0 \cdot 016$ & * \\
\hline Total N & 0.75 & $0 \cdot 73$ & 0.73 & 0.014 & 0.016 & NS \\
\hline \multicolumn{7}{|l|}{ Forestomachs: } \\
\hline Organic matter & $0 \cdot 39$ & $0 \cdot 32$ & 0.36 & 0.022 & $0 \cdot 026$ & $*$ \\
\hline Gross energy & 0.32 & $0 \cdot 21$ & 0.23 & 0.029 & 0.033 & $* * *$ \\
\hline \multicolumn{7}{|l|}{ Small intestine: } \\
\hline Organic matter & 0.33 & $0 \cdot 36$ & 0.33 & 0.037 & 0.042 & NS \\
\hline Gross energy & 0.33 & 0.40 & 0.40 & 0.049 & 0.055 & NS \\
\hline Total N & 0.65 & 0.73 & 0.69 & 0.021 & 0.024 & $* *$ \\
\hline Total NAN & 0.65 & 0.72 & 0.71 & 0.024 & 0.028 & $*$ \\
\hline Microbial NAN & 0.72 & 0.77 & 0.71 & 0.030 & 0.034 & NS \\
\hline Non-microbial NAN & $0 \cdot 56$ & $0 \cdot 67$ & 0.69 & 0.044 & 0.050 & $*$ \\
\hline Ammonia-N & 0.68 & 0.81 & 0.53 & 0.047 & 0.053 & $* * *$ \\
\hline \multicolumn{7}{|l|}{ Large intestine: } \\
\hline Organic matter & $0 \cdot 14$ & $0 \cdot 11$ & 0.11 & 0.029 & 0.032 & NS \\
\hline Gross energy & $0 \cdot 16$ & $0 \cdot 12$ & $0 \cdot 11$ & 0.053 & 0.060 & NS \\
\hline Total $\mathrm{N}$ & $0 \cdot 16$ & 0.09 & $0 \cdot 16$ & 0.063 & 0.071 & NS \\
\hline
\end{tabular}

$n$, number of sheep per treatment; SED, standard error of difference; NS, not significant; NAN, non-ammonia-N.

${ }^{*} P<0.05,{ }^{* *} P<0.01,{ }^{* * *} P<0.001$.

it is common for sheep to acquire a number of parasite species under grazing conditions and their effects could possibly combine synergistically to the detriment of the host. For example, Poppi et al. (1986) have shown that with an infection of Trichostrongylis colubriformis there is incomplete reabsorption of endogenous NAN from the small intestine. Therefore with both $H$. contortus and $T$. colubriformis present it is possible that reabsorption of additional endogenous $\mathrm{N}$ lost from the abomasum as a result of the $H$. contortus infection may be impaired as a result of $T$. colubriformis being present in the small intestine.

\section{Pathophysiology}

The level of infection achieved in this experiment was uniform between animals and similar to that reported in other studies (Allonby \& Dargie, 1973; Abbott et al. 1986) in terms of the number of worms present in the abomasum, their egg production and the level of blood loss into the digestive tract.

In sheep sham-infected by jugular-abomasal blood transfer, the level of anaemia induced was similar to that in sheep infected with $H$. contortus ( 300 larvae/kg live weight), and the estimates of the input of blood into the gastrointestinal tract made using ${ }^{51} \mathrm{Cr}$-labelled erythrocytes were nearly equal to the amounts actually infused. Although the packed cell volume was similar in both the parasitized and sham-infected animals, the blood loss was far lower in the latter group $(253 v .145 \mathrm{ml} / \mathrm{d})$. This was probably due to the more sudden onset of blood loss in the sham-infected animals and the reduced time for erythropoiesis to 
Table 5. Production (irreversible loss rate) and utilization ( $g$ nitrogen/d) of ammonia in the rumen, and production and recycling of urea in the body of sheep: uninfected (controls), infected with Haemonchus contortus or sham-infected by jugular-abomasal blood transfer

(Covariate : total $\mathrm{N}$ intake $(\mathrm{g} / \mathrm{d})$; grand mean $9.90 \mathrm{~g} / \mathrm{d}$ )

\begin{tabular}{|c|c|c|c|c|c|c|c|}
\hline $\begin{array}{ll}n & \ldots\end{array}$ & $\begin{array}{c}\text { Control } \\
\text { (C) } \\
9\end{array}$ & $\begin{array}{l}\text { Parasitized } \\
\text { (P) } \\
5\end{array}$ & $\begin{array}{c}\text { Sham } \\
\text { (S) } \\
5\end{array}$ & $\begin{array}{l}\text { SED } \\
C v . P \\
C v . S\end{array}$ & $\begin{array}{l}\text { SED } \\
\mathrm{P} v . \mathrm{S}\end{array}$ & $\begin{array}{c}\text { Statistical } \\
\text { significance } \\
(F \text { test })\end{array}$ & $\begin{array}{l}\text { Covariate } \\
\text { coefficient }\end{array}$ \\
\hline \multicolumn{8}{|l|}{ Rumen ammonia: } \\
\hline $\begin{array}{l}\text { Concentration } \\
(\mathrm{mg} \mathrm{N} / \mathrm{l})\end{array}$ & 153 & 152 & 141 & $18 \cdot 0$ & $20 \cdot 4$ & NS & 5.6 \\
\hline $\begin{array}{l}\text { Irreversible } \\
\text { loss }(\mathrm{g} \mathrm{N} / \mathrm{d})\end{array}$ & $7 \cdot 00$ & $8 \cdot 01$ & 7.28 & 0.58 & 0.65 & NS & 0.59 \\
\hline $\begin{array}{l}\text { Proportion of } \\
\text { microbial N }\end{array}$ & 0.69 & 0.67 & 0.57 & 0.06 & 0.06 & NS & NS \\
\hline $\begin{array}{l}\text { Proportion of } \\
\text { duodenal ammonia-N }\end{array}$ & 0.60 & 0.34 & 0.54 & 0.05 & 0.06 & $* * *$ & NS \\
\hline $\begin{array}{l}\text { Apparent absorption } \\
(\mathrm{g} \mathrm{N} / \mathrm{d})\end{array}$ & 3.81 & $4 \cdot 40$ & $4 \cdot 24$ & 0.55 & 0.63 & NS & 0.38 \\
\hline $\begin{array}{l}\text { Outflow in fluid } \\
(\mathrm{g} \mathrm{N} / \mathrm{d})\end{array}$ & 0.62 & 0.83 & $0 \cdot 70$ & 0.08 & 0.09 & NS & 0.045 \\
\hline \multicolumn{8}{|l|}{ Ammonia in intestine: } \\
\hline $\begin{array}{l}\text { Duodenal flow } \\
(\mathrm{g} \mathrm{N} / \mathrm{d})\end{array}$ & 0.71 & $2 \cdot 02$ & 1.06 & $0 \cdot 16$ & $0 \cdot 19$ & $* * *$ & NS \\
\hline Ileal flow $(\mathrm{g} \mathrm{N} / \mathrm{d})$ & 0.25 & 0.37 & 0.48 & 0.067 & 0.075 & $*$ & NS \\
\hline \multicolumn{8}{|l|}{ Plasma urea: } \\
\hline $\begin{array}{l}\text { Concentration } \\
\text { (mg N/l) }\end{array}$ & 197 & 183 & 210 & 17 & 19 & NS & NS \\
\hline $\begin{array}{l}\text { Irreversible loss } \\
(\mathrm{g} \mathrm{N} / \mathrm{d})\end{array}$ & 8.9 & $12 \cdot 2$ & $10 \cdot 9$ & 0.87 & 0.98 & $* * *$ & 0.73 \\
\hline Pool size $(\mathrm{g} \mathrm{N})$ & 2.70 & $3 \cdot 48$ & $3 \cdot 19$ & 0.25 & 0.29 & * & 0.13 \\
\hline $\begin{array}{l}\text { Urinary urea } \\
\text { excretion }(\mathrm{g} \mathrm{N} / \mathrm{d})\end{array}$ & 5.53 & 6.94 & 6.06 & 0.41 & 0.46 & $*$ & 0.37 \\
\hline $\begin{array}{l}\text { Urea transfer into } \\
\text { gut }(\mathrm{g} \mathrm{N} / \mathrm{d})\end{array}$ & $3 \cdot 37$ & $5 \cdot 29$ & $4 \cdot 86$ & 0.67 & 0.76 & $*$ & 0.36 \\
\hline
\end{tabular}

$n$, number of sheep per treatment; SED, standard error of difference; NS, not significant. $* P<0.05,{ }^{* * *} P<0.001$.

develop. The reason for the drop in the packed cell volume of the control animals with period of experiment is not clear. Although weight changes were measured over a relatively short period it appears that the parasitized group lost less live weight than the control or sham-infected animals. It is possible that this could be associated with the higher water retention in this group and a change in body composition towards increased total body water as suggested by Abbott et al. (1986).

\section{Effect on rumen function}

It is interesting that a parasitic infection of the abomasum altered fermentation processes and reduced digestion in the reticulo-rumen, i.e. 'upstream' from the site of infection. In the present study there was a faster outflow of liquid from the rumen and a change in the pattern of fermentation towards an increased value for propionate:acetate. Similar changes in the pattern of VFA production have been found where fluid turnover rate in the 
Table 6. Water intake, flow through the gastrointestinal tract and excretion in urine $(l / d)$ in sheep: uninfected (control), infected with Haemonchus contortus or sham-infected by jugular-abomasal blood transfer

(Covariate: dry matter intake $(\mathrm{g} / \mathrm{d})$; grand mean $430 \mathrm{~g} / \mathrm{d}$ )

\begin{tabular}{|c|c|c|c|c|c|c|c|}
\hline$n \quad \ldots$ & $\begin{array}{c}\text { Control } \\
\text { (C) } \\
9\end{array}$ & $\begin{array}{c}\text { Parasitized } \\
\text { (P) } \\
5\end{array}$ & $\begin{array}{c}\text { Sham } \\
\text { (S) } \\
5\end{array}$ & $\begin{array}{l}\text { SED } \\
\text { C v. P } \\
\text { C v. S }\end{array}$ & $\begin{array}{l}\text { SED } \\
P v . S\end{array}$ & $\begin{array}{c}\text { Statistical } \\
\text { significance } \\
(F \text { test })\end{array}$ & $\begin{array}{l}\text { Covariate } \\
\text { coefficient }\end{array}$ \\
\hline Intake & $1 \cdot 84$ & $2 \cdot 25$ & $1 \cdot 70$ & $0 \cdot 14$ & $0 \cdot 16$ & $*$ & 0.0024 \\
\hline Rumen outflow & 4.05 & 5.53 & $4 \cdot 84$ & 0.43 & $0-48$ & $* *$ & 0.0034 \\
\hline Duodenal flow & $4 \cdot 75$ & $6 \cdot 32$ & $5 \cdot 52$ & 0.52 & 0.59 & * & 0.0039 \\
\hline Ileal flow & 1.93 & 1.97 & 1.99 & 0.22 & 0.25 & NS & 0.0030 \\
\hline Excretion in faeces & $0 \cdot 36$ & 0.23 & $0 \cdot 20$ & 0.42 & $0 \cdot 48$ & $* *$ & 0.00045 \\
\hline Excretion in urine & 0.95 & $1 \cdot 19$ & 0.97 & 0.15 & 0.17 & NS & 0.0012 \\
\hline $\begin{array}{l}\text { Apparent water } \\
\text { retention }\end{array}$ & $0 \cdot 52$ & 0.87 & 0.51 & $0 \cdot 15$ & $0 \cdot 17$ & $\dagger$ & NS \\
\hline \multicolumn{8}{|c|}{ Absorption coefficients: } \\
\hline Forestomachs & $-1 \cdot 61$ & -1.72 & $-2 \cdot 66$ & 0.35 & 0.40 & * & NS \\
\hline Small intestine & 0.60 & 0.67 & 0.65 & 0.05 & 0.06 & NS & NS \\
\hline Large intestine & 0.80 & 0.88 & 0.90 & 0.03 & $0 \cdot 04$ & $*$ & NS \\
\hline
\end{tabular}

$n$, number of sheep per treatment group; SED, standard error of difference; NS, not significant. $\dagger P<0 \cdot 10, * P<0 \cdot 05, * * P<0 \cdot 01$.

rumen is increased through infusions of artificial saliva (Harrison et al. 1975), through increased reticulorumen motility in animals subjected to cold exposure (Westra \& Christopherson, 1976; Kennedy \& Milligan, 1978), and in ruminants given a range of antibiotics specific against certain types of bacteria (e.g. see Chalupa, 1980). It therefore appears that the effect of a postrumen parasitic infection on the pattern of fermentation can either be through altered reticulorumen motility or a more specific effect on the microbial population, or both. Although the parasitized sheep drank significantly more water than the uninfected control animals it is unlikely that this affected fluid flow through the rumen or the pattern of fermentation since intrarumen infusions of water have been shown to have no effect on these variables (Harrison et al. 1975). In studies on the effect on motor and transit disturbances, Bueno et al. (1982) reported an increased rate of duodenal-migrating myoelectric complexes and a shortened cycle of antral contractions of the abomasum in sheep infected with $H$. contortus. The authors suggested that these changes resulted from alterations to abomasal acid secretions and to ionic permeability in the gastrointestinal mucosa. It is possible that these changes also affect reticulorumen motility.

On the other hand Steel (1972) found a $62 \%$ reduction in rumen acetate production without any change in rumen fluid outflow in sheep infected with the intestinal parasite $T$. colubriformis. It appears that $T$. colubriformis has little or no effect on gastrointestinal motility (see Gregory, 1985) and it is therefore possible that a postrumen nematode infection may alter rumen fermentation without affecting fluid flow rate.

\section{$N$ digestion and metabolism}

The overall effect of $H$. contortus parasitism and of blood transfer into the abomasum of the sham-infected sheep was to increase $\mathrm{N}$ loss in urine. A detailed summary of $\mathrm{N}$ movement in the gastrointestinal tract and tissues is given in Fig. 3. This summary is based on values given in Tables 3 and 5, and the measured loss of blood into the abomasum. The contribution of plasma urea to rumen ammonia was not measured in the present study and 


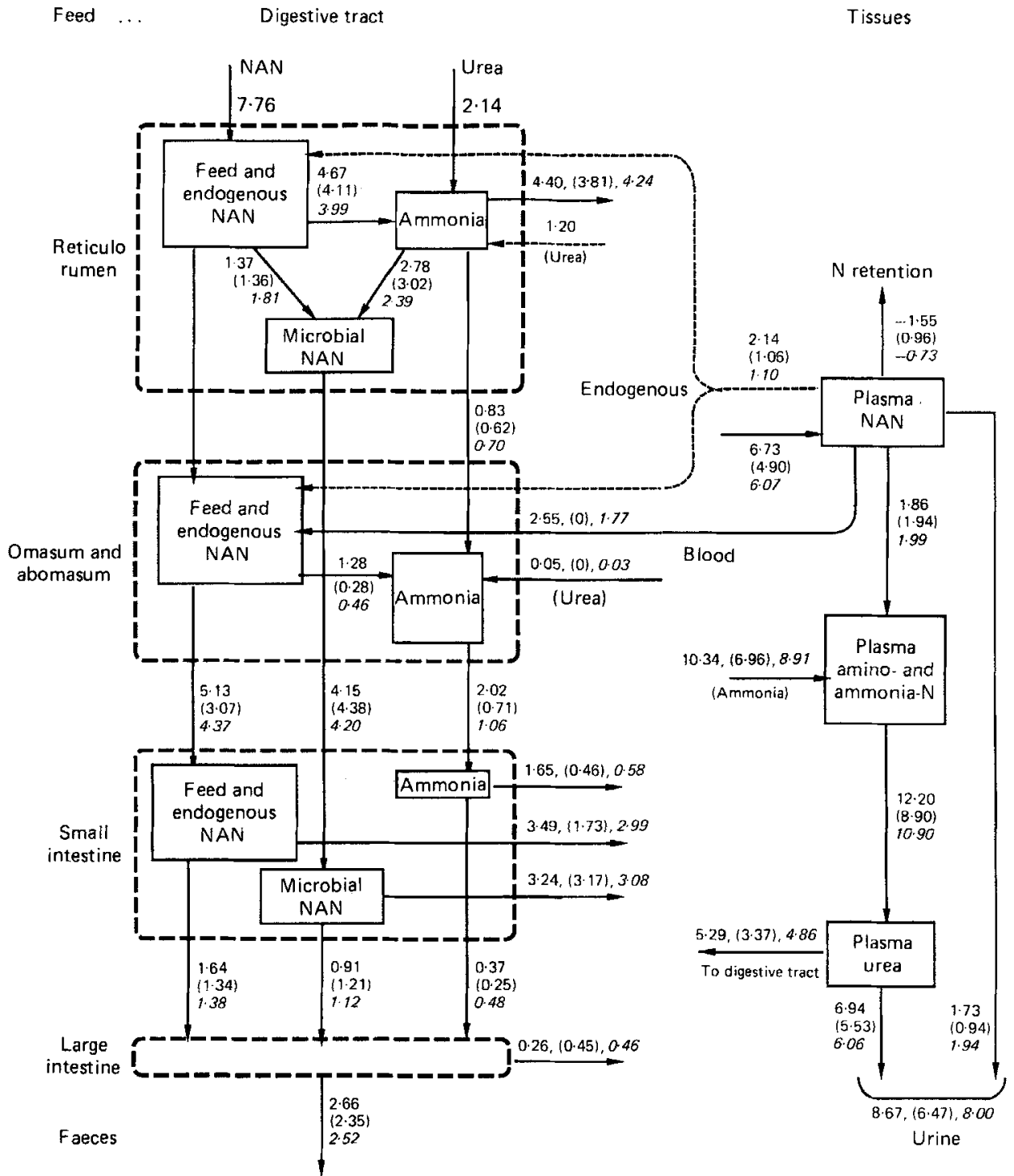

Fig. 3. Nitrogen transactions ( $\mathrm{g} \mathrm{N} / \mathrm{d}$ ) in the digestive tract and tissues of sheep: uninfected (control) ( $n$ 9), infected with the parasite Haemonchus contortus ( $n$ 5) or sham-infected by jugular-abomasal blood transfer $(n 5)$. Values for uninfected sheep are given in parentheses, and for sham-infected sheep in italics. Only a single value is given for intakes representing the mean across all treatments. NAN, non-ammonia-N.

the value $1.2 \mathrm{~g} \mathrm{~N} / \mathrm{d}$ reported by Nolan \& Leng (1972) for sheep continuously fed on a similar diet has been used in Fig. 3. The flow of $\mathrm{N}$ from the 'feed and endogenous NAN' compartment in the 'omasum and abomasum' to 'ammonia' was calculated from the flow of ammonia to the duodenum and its ${ }^{15} \mathrm{~N}$ enrichment (see Siddons et al. 1985). The flow of endogenous NAN to the forestomachs was calculated once other flows through the compartments in the reticulorumen and omasum-abomasum had been determined. In Fig. 3 the entry of ammonia to the 'plasma amino- $\mathrm{N}$ and ammonia-N' compartment, to 
account for plasma urea production, exceeds the total amount apparently absorbed. This is to be expected since the absorption of ammonia from the rumen was determined without accounting for recycling of ${ }^{15} \mathrm{~N}$ to the rumen and is therefore a minimum value. In addition Siddons et al. (1985) measured two-way flows of $\mathrm{N}$ between plasma urea and the ammonia compartments in the omasum-abomasum, and the small and large intestines. In our studies only net flows were measured and are therefore likely to underestimate actual values.

The estimated conversion of feed or endogenous NAN, or both, to ammonia in the omasum-abomasum of control animals $(0.28 \mathrm{~g} \mathrm{~N} / \mathrm{d})$ was similar to that reported by Siddons et al. (1985) $(0.3-0.4 \mathrm{~g} \mathrm{~N} / \mathrm{d})$, and increased to 0.46 and $1.28 \mathrm{~g} \mathrm{~N} / \mathrm{d}$ in the shaminfected and parasitized animals respectively. It is likely that part of the additional ammonia produced in the abomasum of the parasitized animals was as a result of metabolism of blood protein by $H$. contortus in energy-yielding pathways. It is clear that the breakdown of blood protein also occurs independently of the parasite's metabolism since in the sham-infected group the breakdown of NAN to ammonia was also increased. Most of the additional ammonia-N and NAN flowing from the abomasum was absorbed from the small intestine which suggests that neither the infection nor loss of blood into the abomasum impaired post-abomasal digestive function. There was more urea synthesis from ammonia, more urea excretion and increased recycling of urea to the gastrointestinal tract in parasitized animals. In addition to the higher excretion of urea in the urine there was more non-urea- $\mathrm{N}$ excretion which indicates poor re-utilization of the reabsorbed $\mathrm{N}$ for protein synthesis at the tissue level. The increased production of urea- $\mathrm{N}$ and its loss in urine as a result of increased protein turnover in parasitized sheep has also been reported for T. colubriformis infections (Roseby \& Leng, 1974) in which protein is lost into the small intestine principally as sloughed cells and mucin rather than as blood. There were no differences in apparent ammonia absorption from the rumen, but there was a suggestion of differences in absorption of ammonia from the large intestine of the parasitized animals compared with the sham-infected and control groups. In this regard it is interesting that there was a gain in NAN between the ileum and rectum in parasitized animals and a loss in the sham-infected and control animals. This implies a greater fermentation activity in the large intestine of the parasitized animals.

It was therefore concluded that depressed production in sheep infected with $H$. contortus results principally from an irreversible loss of protein brought about by blood loss and the haematophagous habits of the parasite within the abomasum. The decrease in availability of essential amino acids is likely to have a disproportionate effect on wool production which is particularly sensitive to the availability of S-containing amino acids. In chronic infections reduced feed intake has been shown to be important (Abbott et al. 1986) but the possible reasons for inappetence were not examined directly in the present study.

P.H.H. was in receipt of a Wellcome-Ramaciotti Research Travel Grant. The authors wish to thank Miss K. Tanaka and Messrs P. J. Murray, S. Stachiw (University of New England), W. R. King and D. Devereaux for their major assistance in sample preparation and analysis. Mr J. Wallace gave advice and assisted with the statistical analyses. Special gratitude is extended to Mr I. Southey for his characteristic assistance in the management of the experimental animals.

\section{REFERENCES}

Abbott, E. M., Parkins, J. J. \& Holmes, P. H. (1986). Veterinary Parasitology 20, 291-306.

Albers, G. A. A., Le Jambre, L. F., Barker, J. S. F. \& Piper, L. R. (1984). Proceedings of the Australian Society of Animal Production 15, 647.

Allonby, E. W. \& Dargie, J. D. (1973). In Helminth Diseases of Cattle, Sheep and Horses in Europe, pp. 59-71. [G. M. Urquhart and J. Armour, editors]. Glasgow University Press: Robert Maclehose \& Co Ltd. 
Altaif, K. I. \& Dargie, J. D. (1978). Parasitology 77, 161-176.

Binnerts, W. T., Van't Klooster, A. Th. \& Freus, A. M. (1968). Veterinary Record 82, 470.

Bueno, L., Dakkak, A. \& Fioramonti, J. (1982). Parasitology 84, 367-374.

Chalupa, W. (1980). In Digestive Physiology and Metabolism of Ruminants, pp. 325-347 [Y. Ruckebusch and P. Thivend, editors]. Lancaster: MTP Press.

Cocimano, M. R. \& Leng, R. A. (1967). British Journal of Nutrition 21, 353-371.

Dargie, J. D. (1975). In Pathogenic Processes in Parasitic Infections, pp. 1-26 [A. E. R. Taylor and R. Muller, editors]. Oxford: Blackwell Scientific Publications.

Faichney, G. J. (1975). In Digestion and Metabolism in the Ruminant, pp. 277-291 [1. W. McDonald and A. C. I. Warner, editors]. Armidale: University of New England Publishing Unit.

Gordon, H. McL. \& Whitlock, H. V. (1939), Journal of CSIR 12, 50-52.

Gregory, P. C. (1985). In Veterinary Research Communication, vol. 1. The Ruminant Stomach, pp. 267-286 [L. A. A. Ooms, A. D. Degryse and R. Marsboom, editors]. Beerse, Belgium: Jansen Research Foundation.

Harrison, D. G., Beever, D. E., Thomson, D. J. \& Osbourn, D. F. (1975). Journal of Agricultural Science, Cambridge, 85, 93-101.

Holmes, P. H. (1985). Veterinary Parasitology 18, 89-101.

Kennedy, P. M. \& Milligan, L. P. (1978). British Journal of Nutrition 39, 105-117.

Leng, R. A., Gill, M., Kempton T. J., Rowe, J. B., Nolan, J. V., Stachiw, S. \& Preston T. R. (1981). British Journal of Nutrition 46, 371-384.

Marsh, W. H., Fingerhut, B. \& Kirsch, E. (1957). American Journal of Clinical Pathology 28, 681.

Nolan, J. V. \& Leng, R. A. (1972). British Journal of Nutrition 27, 177-194.

Poppi, D. P., MacRae, J. C., Brewer, A. \& Coop, R. L. (1986). British Journal of Nutrition 55, 593-602.

Roseby, F. B. \& Leng, R. A. (1974). Australian Journal of Agricultural Research 25, 363-367.

Rowe, J. B., Abbott, E. M., Dargie, J. D. \& Holmes, P. H. (1982). Proceedings of the Nutrition Society 41, $74 \mathrm{~A}$.

Siddons, R. C., Nolan, J. V., Beever, D. E. \& MacRae, J. C. (1985). British Journal of Nutrition 54, $175-187$.

Steel, J. W. (1972). Proceedings of the Australian Society of Animal Production 9, 402-407.

Steel, J. W. (1974). Proceedings of the Australian Society of Animal Production 10, 139-147.

Steel, J. W. (1978). In Recent Advances in Animal Nutrition in Australia, pp. 98-109 [D. J. Farrell, editor]. Armidale: University of New England.

Thomas, R. J. \& Ali, D. A. (1983). International Journal for Parasitology 13, 393-398.

Westra, R. \& Christopherson, R. J. (1976). Canadian Journal of Animal Science 56, 699-708. 